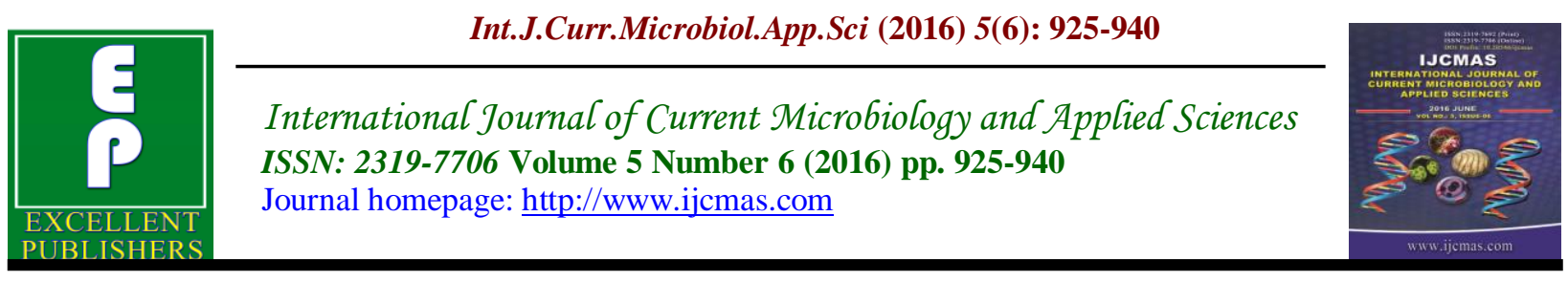

Original Research Article

http://dx.doi.org/10.20546/ijcmas.2016.506.100

\title{
North African Paleozoic- Mesozioic Foraminifera (Biostratigraphy and Echostratigraphy)
}

\author{
S. Abd El-Azeam*, Nagwa Ibrahim, E. Abd-Elshafy and Yahia Naglaa \\ Geology Department, Faculty of Science, Zagazig University, Egypt \\ *Corresponding author
}

\begin{abstract}
A B S T R A C T
Keywords

Bahrein;

Paleozoic;

Mesozoic;

Foraminifera;

Biostratigraphy,

ecozones.

Article Info

Accepted:

22 April 2016

Available Online:

10 June 2016

The studied 152 ditch samples have been selected from the Bahrein -1 Well. The main aim is to investigate the foraminiferal assemblages of the Paleozoic- Mesozoic succession in terms of abundance and diversity, to determine their biostratigraphic assignments and the palaeoenvironmental interpretations. 124 foraminiferal species have been identified from the Paleozoic- Mesozoic sedimentary succession of Bahrein area in West Egypt. Eight biozones have been recognized within the studied succession. They are six in the Paleozoic followed unconformably by one Jurassic biozone which intern is overlain unconformably by other Lower Cretaceous one. Some of these zones have regional extension while others represent the first try of biozonation in the Lower Paleozoic as a whole. These subsurface Paleozoic- Mesozoic successions have been differentiated ecostratigraphically into five echostratigraphic units, each with its distinctive paleoenvironment.
\end{abstract}

\section{Introduction}

The Bahrein area in the northwestern part of the Egyptian Western Desert was penetrated by the Bahrein -1 bore whole at Lat $.28^{\circ} 48$ $10^{\prime \prime} \mathrm{N}$ and Long . $26^{\circ} 3315^{\prime \prime} \mathrm{E}$ (Fig.1). The studied bore whole meet the PaleozoicMesozoic succession between depth 2853 m and depth $1200 \mathrm{~m}$. It includes the main part of the Paleozoic, the Jurassic and the basal part of the Lower Cretaceous. The studies of Osman (1956), Said and Andrawis (1961), Ebeid (1969), Andrawis (1972), Barthel and Boettcher (1978), Abd- Elshafy (1977,1984,1990), Hassan et al. (1978a,b,c), Abd Elsattar $(1979,1982)$, Klitzsch and Nicol (1984), Hassanein and Arafa (1989), Ibrahim(1992), Abd-Elshafy et al., (1998), El Hariri (2008) and Yahia (2010) are the most prominent.

Lithostratigraphically the succession was attributed to the Zeitoun Formation (Ordovician-Early Silurian), Acacus 
Formation (Silurian), Kohla Formation (Late Silurian- Devonian), Bahrein Formation (Early Jurassic) and Betty Formation (Early Cretaceous) by Abd Elshafy et.al.(2012) in press.

\section{Materials and Methods}

The present work depends on 152 ditch samples covering the total studied thickness $(1653 \mathrm{~m})$. All rock samples were prepared for studying their foraminiferal content. The recorded foraminiferal species were biostratigraphically studied throughout the succession under consideration according to the commonly known techniques and chronostratigraphically dealt for the age assignment.

\section{Results and Discussion}

\section{Biostratigraphy}

Investigation of stratigraphic distribution of the identified 124 foraminiferal species (Figs.2, 3), led to the recognition of eight biozones within the studied PaleozoicMesozoic succession. These biozones are one in the Ordovician, 2 in the Silurian, 3 in the Devonian followed unconformably by one Jurassic biozone which inturn is overlain unconformably by other Lower Cretaceous one. The boundaries among the Paleozoic biozones are conformable relations. Stratigraphically the differentiated zones (Figs.2, 3) run as follow:

\section{Amphitremoida Laevis - Granulodiscus Bahreinensis Assemblage Zone}

This zone begins with the base of the studied part of the well, at depth $2853 \mathrm{~m}$ and extends to depth $2508 \mathrm{~m}$. It occupies most of the Zeitoun Formation (345m) with unknown true base and underlies conformably the Silurian Bathysiphon exiguus - Psammosphaera angularis
Assemblage Zone (Fig.2).

The present base of this zone is placed with the beginning of the first studied sample which bears the first appearance of Granulodiscus bahreinensis, Amphitremoida orbicularis Nestell and Tolmacheva, while its top is marked by the disappearance of its characterizing species and the first appearance of typical Silurian species.

The interval of the zone is characterized by the occurrence of the Ordovician foraminifers Amphitremoida laevis Nestell and Tolmacheva, A. orbicularis Nestell and Tolmacheva, Hyperammina conica Gutschick, Weiner and Young, Hyperammina? Rudis Parr and Psammophax sp.

\section{Bathysiphon Exiguus - Psammosphaera Angularis Assemblage Zone}

This zone (120m) lies between depth 2508 $\mathrm{m}$ and $2388 \mathrm{~m}$ to comprise the upper part of the Zeitoun Formation and the lower part of Acacus Formation. It is confined conformably between the underlying Ordovician Amphitremoida laevis Granulodiscus bahreinensis Assemblage Zone and the overlying Silurian Rhabdammina bifurcata - Raibosammina aspera Assemblage Zone.

This Silurian biozone starts with the disappearance of the typical Ordovician species and the first appearance of the Silurian ones as Bathysiphon exiguus Moreman, B.rugosus Ireland, Psammosphaera angularis Ireland, P.subsphaerica Dunn, Serpenulina uralica Chernykh, Polysaccammina sp., Scyphocodon verrucosus Kristan and Tollmann, Raibosammina sp. Browne and Schott, Hyperammina harrisi Ireland (Fig.2). 
Rhabdammina Bifurcata - Raibosammina Aspera Assemblage Zone

This zone is represented by the main part of Acacus Formation and the lower part of Kohla Formation where it ranges from depth $2383 \mathrm{~m}$ to $2094 \mathrm{~m}$, to sum $294 \mathrm{~m}$ thickness.

The zone under consideration is conformably overlying Bathysiphon exiguus - Psammosphaera angularis Assemblage Zone and underlying the Devonian Psammosphaera devonica - Sorosphaera multicella Assemblage zone. It begins with the first appearance of Granulodiscus constrictus. Sorostomosphaera waldronensis McClellan, Raibosammina mica Moreman, Rhabdammina bifurcata Brown and Schott, Thurammina arcuata Moreman. The zone ends with the disappearance of the Silurian type species. The other Silurian forams. Raibosammina aspera Moreman, Thurammina sphaerica Ireland, Webbinelloides globulosa McClellan, Psammosphaera gracilis Ireland, Pseudohyperammina sp., Lagenammina cf. wallingfordensis (Conkin), Colonammina verruca Moreman, Hyperbathoides schwalmi Ireland are the characteristic species (Fig.2).

\section{Psammosphaera Devonica - Sorosphaera Multicella Assemblage Zone}

It lies within the Kohla Formation between depth from $2094 \mathrm{~m}$ to $1947 \mathrm{~m}$, where it conformably overlies the topmost Silurian zone and underlies conformably the Devonian Oxinoxis ligula - Saccammina granulata Assemblage Zone.

The zone in question begins with the first appearance of the Devonian species Psammosphaera devonica Stewart and Lampe, Sorosphaera multicella Dunn, Kechentiske cf expansus (Plummer),
Tolypammina bulbosa (Gutschick and Treckman), while its top is marked by the disappearance of most of its nominate species. These species, as well as Sorosphaera. osgoodensis Stewart and Lampe, Ammobaculites stenomeca Cushman and Water, Psammosphaera pussila Parr, $P$. gigantea Dunn, Hyperammina cf castri Conkin, and H. rockfordensis Gutschick and Treckman, Thurammina subpapillata Ireland, Th. sphaerica Ireland assert Devonian age for this biozone (Fig.2).

\section{Oxinoxis Ligula - Saccammina Granulata Assemblage Zone}

This Devonian biozone is recognized in the upper part of Kohla Formation between depths 1947 - 1767 m. It conformably overlies Psammosphaera devonica Sorosphaera multicella Assemblage Zone and underlies Sorosphaera bicella Psammosphaera cava Assemblage Zone. Its lower limit is marked by the first appearance of Saccammina granulata n.sp, Psammophax globulata, Oxinoxis ligula (Gutschick, Weiner and Young). While its top is marked by the disappearance of the nominate species.

Saccammina ingloria Bykova, Thurammina sphaerica Ireland, Th. Subpapillata Ireland, Hyperammina constricta Gutschick and Treckman, Lagenammina bulbosa Dunn, Psammosphaera gigantea Dunn, Webbinelloides similis Stewart and Lampe in addition to the nominate species are the characteristic species of this zone (Fig.2).

\section{Sorosphaera Bicella - Psammosphaera cava Assemblage Zone}

This zone marks the end of the Devonian in the studied well; it represents the upper 420 $\mathrm{m}$ of Kohla Formation, lying between depths $1767 \mathrm{~m}$ and $1347 \mathrm{~m}$. It follows conformably 
Oxinoxis ligula - Saccammina granulata Assemblage Zone and underlies unconformably the Jurassic Problematina liassica - Trochammina kingakensis Assemblage Zone

The first appearances of Saccammina globulata, Nephrosphaera minuta, define the base of this zone, while its top is marked by the disappearance of Sorosphaera bicella Dunn, Nephrosphaera minuta, Reophax biloculus, Psammosphaera cava Moreman and Sorosphaera tricella Moreman.

The Devonian species Sorosphaera confusa Brady, S. papilla Gutschick and Treckman, S. subconfusa Dunn, Psammosphaera cava Moreman, $P$. rugosa Eisenack, $P$. aspeara Summerson, $P$. rotunda Stewart and Lampe, $P$. gigantea Dunn, Th. Papillata var monticulifera Ireland, Th. diforamens Ireland, Th. quadrata Dunn, Th. subpapillata Ireland, Saccammina glensteri Crespin, S. Stilla (Moreman), Trochammina sp. Cushman and Waters, Nephrosphaera fissurata Kristan - Tollmann, Bathysiphon parallelus Dunn, B. rugosus Ireland, Webbinelloides similis Stewart and Lampe, Tolypammina diforamens Ireland, $T$. Jacobschapelensis Conkin, Hyperbathoides schwalmi Ireland are the main components of this zone (Fig.3).

\section{Problematina Liassica - Trochammina Kingakensis Assemblage Zone}

This zone is present through the Bahrein Formation ranging in depth from $1347 \mathrm{~m}$ to $1230 \mathrm{~m}$, where it unconformably overlies the preceding Devonian Zone and underlies unconformably the Lower Cretaceous Nezzazata spp. Assemblage Zone.

The beginning of this zone is defined with the first appearance of the typical Jurassic species Problematina liassica (Jones), Trochammina kingakensis (Tappan), $T$. lathetica Loeblich and Tappan, T. constricta Haeusler, Thuramminoides lapilliforms Nagy and Basov, Ammobaculites. cf. A. superajurassicus (Schwager), and its top is marked by the disappearance of the Jurassic species and starting of definite Lower Cretaceous species.

These formentioned Jurassic foraminiferal species as well as, Trochammina $c f$. depressula Said and Barakat, , T. Sablei Tappan, T. squamata Jones and Parker, Saccammina polygona , Evolutinella barrawensis Tappan, Ammobaculites sp., A. superajurassicus (Schwager), Haplophragmoides globosum. Seibold and Seibold are the members of this zone, so it is assigned to the Jurassic (Fig.3).

\section{Nezzazata Spp. Assemblage Zone}

This is the uppermost biozone in the studied well, it is found in the recorded part of Betty Formation, through $30 \mathrm{~m}$ thickness from depths $1230 \mathrm{~m}$ to $1200 \mathrm{~m}$. It unconformably overlies the preceding Problematina liassica - Trochammina kingakensis Assemblage Zone and its top is undefined due to the non availability of rock sample younger than depth 1200m (fig.3) at the end of the studied succession.

The sudden and complete disappearance of the Jurassic species define the beginning of this zone as well as the first appearance of Early Cretaceous typical species as Nezzazata spp, Leganammina alexanderi (Loeblich and Tappan), Rhizammina indivisa Brady, Trochamminoides coronus Loeblich and Tappan, Recurvoides sp. Saint Marc and N'Da, Evolutinella Cushmani (Loeblich and Tappan), Daxia sp. and others.

The Early Cretaceous Nezzazata isabella Arnaud and Sliter, N. sp.c Arnaud and Silva, N. lobulata n.sp., Evolutinella subevoluta 
Nikitina and Myatlyuk, E. vocantianus (Moullade), E. cushmani Loeblich and Tappan, Recurvoides obskiensis Romanova, Ammobaculites tyrelli Nauss, A. indicus Bhalla, Simobacuites raghavapuramensis (Bhalla), Asanospira teshiansis (Asano), Trochamminoides coronus Loeblich and Tappan, Trochammina cf. globigerniformis (Parker and Jones) are the main components of this zone (Fig.3).

\section{Paleoenvironment}

Depending on the main lithologic characteristics, general sequenciallity of strata, ecologic habit of the recorded foraminiferal species and their associations, five ecozones have been differentiated. They run statigraphically as following.

\section{Ecozone- I}

Interval: from depth: 2853 to 2508 .

Age: Ordovician.

\section{Lithology}

It occupies the main part of Zeitoun Formation (Fig. 2). This interval consists of colorless to light pink, moderately compact, micaceous, ferruginous and kaolinitic sands and colorless to light pink, tan, fine to coarse grained, subangular to subrounded, ferruginated sandstones with few red to brown, soft, sticky, sandy shale interbeds. These lithologic characteristics reflect deposition under shallow marine or beach environment according to Folk (1980) and Tuker (1981).

\section{Foraminiferal Content}

This ecozone conforms in its limits with the foraminiferal Amphitremoida laevis Granulodiscus bahrainensis Assemblage Zone (Yahia, 2010). It contains several agglutinated foraminifers of the genera Amphitremoida,

Hyperammina,
Psammophax, Granulodiscus, Bathysiphon and Psammosphaera. These small agglutinated foraminifera characterize the shallow marine environment of high energy (Boltovskoy and Wright, 1976; Said and Barakat, 1958; Abd- El-Azeam, 1985; Abd Elshafy, 1990 and Abd Elshafy et al., 2000) considered the Hyperammina and the Psammosphaera as shallow marine indicators.

\section{Probable palaeoenvironment}

The lithologies as well as the moderate diversity of the agglutinated foraminiferal content suggest shallow marine near shore restricted basin for the sedimentary interval of the present ecozone.

Ecozone - II

Interval: From depth 2508 to $2210 \mathrm{~m}$.

Age: Silurian

\section{Lithology}

This ecozone is recognized through the strata occupying the upper part of the Zeitoun Formation, the Acacus Formation and the lower part of Kohla Formation (Fig. 2 ). It is composed mainly of grey to light grey compact, fissile, micaceous, shales, containing carbonaceous matter and highly calcareous siltstone interbeds at the lower part grading into white to pale grey, compact to highly compact, argillaceous, glauconitic, calcareous, micaceous siltstone, sandy upward. It contains basaltic igneous intrusion in its middle part. The shale component suggests low energy environment where the fine grained sediments most probably were settled from suspension, while the silt beds and interbeds reflect intervals of terrigeneous outlet (Selley, 1978; Abd-Elshafy et al., 1990 and Abd-Elshafy et al., 2000). 


\section{Foraminiferal Content}

The present ecozone includes the foraminiferal individuals with simple, small, unornamented agglutinated walls of the genera Bathysiphon, Psammosphaera, Polysaccammina, Scyphocodon, Hyperammina Rhabdammina, Raibosammina, Thurammina Sorostomosphaera Psammophax, Nephrosphaera, Webbinelloides, Pseudohyperammina, Lagenammina, and Colonammina and Hyperbathoides which predominate mostly in the shallow shelf area (Haq and Boersma ,1978 and Abd-Elshafy, 1990)

\section{Probable Paleoenvironment}

The litho and the biofacies of this ecozone indicate the prevalence of a quite marine shallow shelf area during the deposition of its sediments.

Ecozone - III

Interval: from depth 2210 to $1347 \mathrm{~m}$.

Age: Devonian (Fig. 3).

\section{Lithology}

This ecozone comprises the Kohla Formation. Its interval is formed mainly from white and brown, moderately compact, highly ferruginous, calcareous in parts, dolomitic in other parts, micaceous, and kaolinitic sandstones with friable, fine to very coarse, rounded to subrounded, moderately sorted and calcareous sands, with much carbonaceous matter interbedded with thin bands of green to grey hematitic, gypseous and moderately compact shale, in the middle and the upper parts. The upper shale bands bear some very thin coal bands. These lithologies reflect deposition under shallow marine or beach environment with interruption of fluviatile intervals (Folk, 1980; Tuker, 1981).

\section{Foraminiferal Content}

The interval of this zone includes the intervals of the foraminiferal Psammosphaera devonica - Sorosphaera multicella Assemblage zone, Oxinoxis ligula - Saccammina granulata Assemblage zone, Sorosphaera bicella - Psammosphaera cava Assemblage Zone of (Yahia, 2010). It is rich with the benthic agglutinated Devonian foraminiferal species as Psammosphaera, Kechentiske, Ammobaculites, Tolypammina, Hyperammina, Thurammina, Oxinoxis Saccammina, Psammophax, Lagenammina, Webbinelloides, Sorosphaera, Saccammina, Nephrosphaera, Bathysiphon, Psammophax, Hyperbathoides, Schyphocodont and Reophax. Such associations suggest deeper marine environment (middle to outer shelf area) according to Haq and Boersma (1978), Abd-Elshafy et al (1990) and Abd-Elshafy et al (2000).

\section{Probable Environment}

The lithological characters and the high diversity of the agglutinated foraminifera suggest the deposition on an unstable shallow to middle shelf area. On the other hand the presence of coal bands in the upper shaley and sandy parts reflects the proximity of the shore line under an arid climate.

Ecozone - IV

Interval: from depth 1347 to $1230 \mathrm{~m}$.

Age: Early Jurassic

\section{Lithology}

The sedimentary succession of this ecozone represents the Jurassic sequence (Bahrein Formation) in the studied well (Fig. 3). It is composed of colorless and red sandstones with thin bands of shales. The sandstones are moderately compact, silty and sandy, 
with fine to coarse, angular quartz grains, calcareous and ferruginated. The shales are light grey to grey, moderately compact, sticky, thinly bedded, calcareous, sandy and silty, graded to siltstone upwards. These facies reflect deposition within a lagoon environment in unstable basin.

\section{Foraminiferal Content}

Strata of this interval are devoid from any calcareous forms and characterized by low diversity, common to rare occurrence of small size arenaceous species, as the individuals of Trochammina and rare members of Ammobaculites, Natiloculina, Ammodiscus,

Problematina,

Thuramminoides and Saccammina. These forms are commonly found in sediments mostly were attributed to near- shore, shallow water environments having low salinity and low PH values, such as certain mashes of lagoons (Bandy, 1960). Rarity of calcareous forms also suggests a shallow, brackish water environment such as lagoon (Bandy, 1963; Abd-Elshafy, 1990; AbdElshafy and Ibrahim, 1987; Abd-Elshafy et al. 1990, 1998 a, b, 2009 and Ibrahim, 1992).

Probable environment: Shelf lagoon environment in unstable basin, becoming shallower upwards.

Ecozone - V

Interval: From depth 1230 to $1200 \mathrm{~m}$.

Age: Early Cretaceous

\section{Lithology}

The present ecozone represents the available studied part of the Lower Cretaceous sediments (30m thick) in Betty Formation (Fig.3). It is represented by light grey to greenish grey, moderately compact, sticky and silty shale with very fine to coarse grained and colorless sandstone. These lithologies reflect deposition in a shallow marine environment, interrupted by calm intervals of low energy represented by shales (Boggs, 1987).

Fig.1 Location Map of the Studied Area

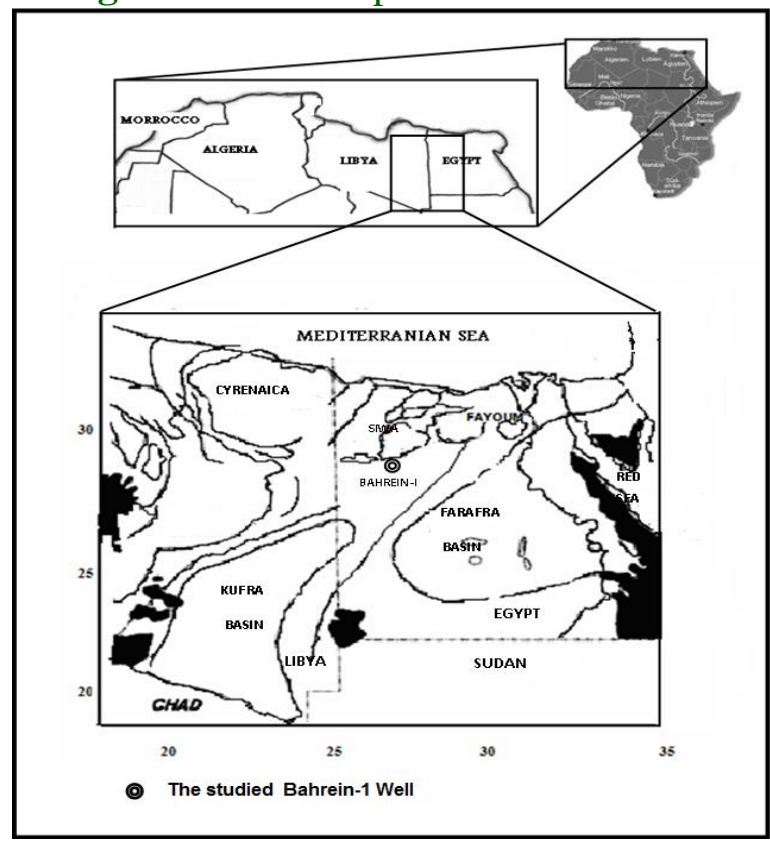


Figure.2 Biostratigraphic Succession of the Paleozoic Rocks in Bahrein-1 Well, Northwestern of Western Desert

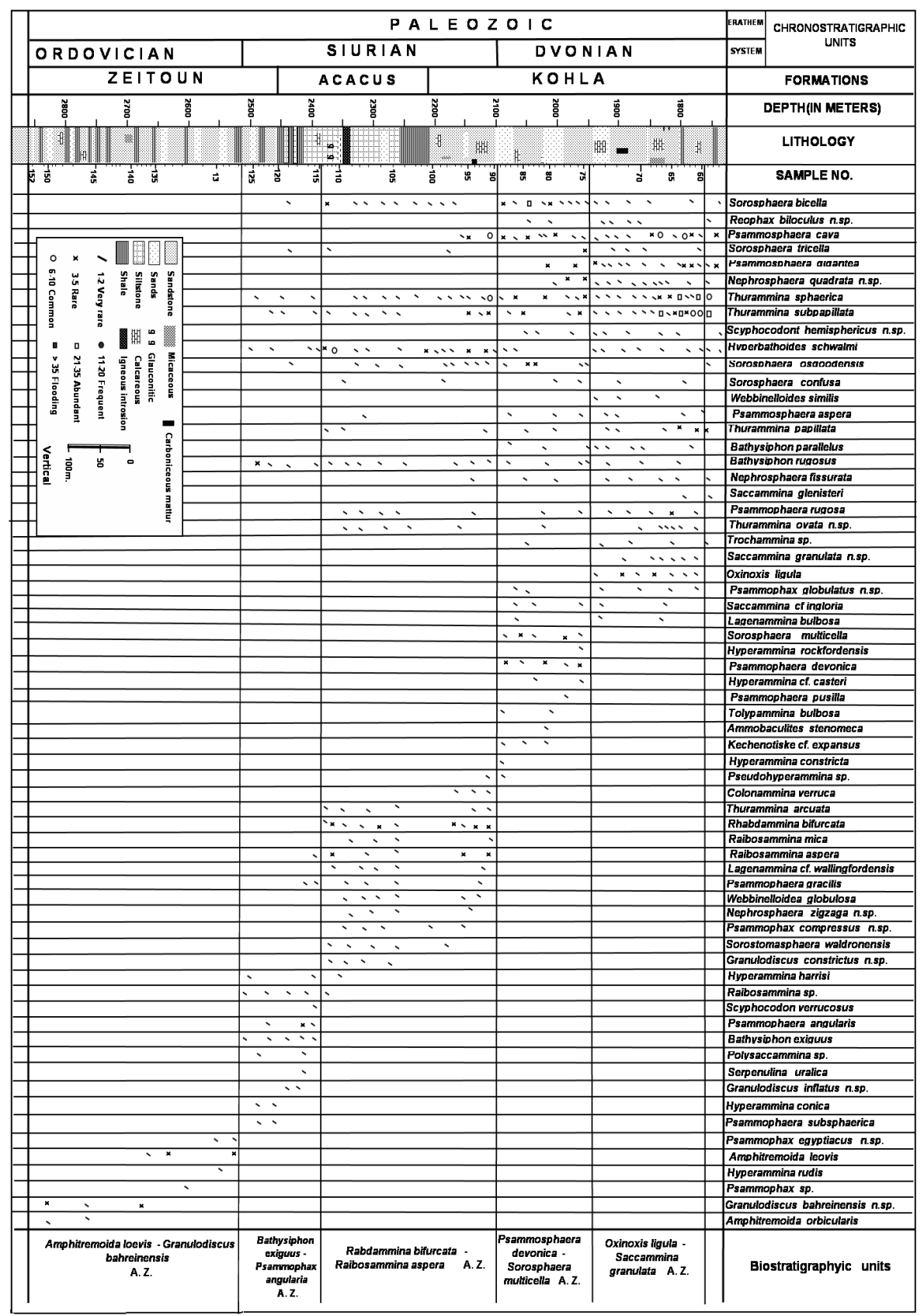


Figure.3 Biostratigraphic Succession of the Paleozoic - Mesozoic Rocks in Bahrein-1 Well

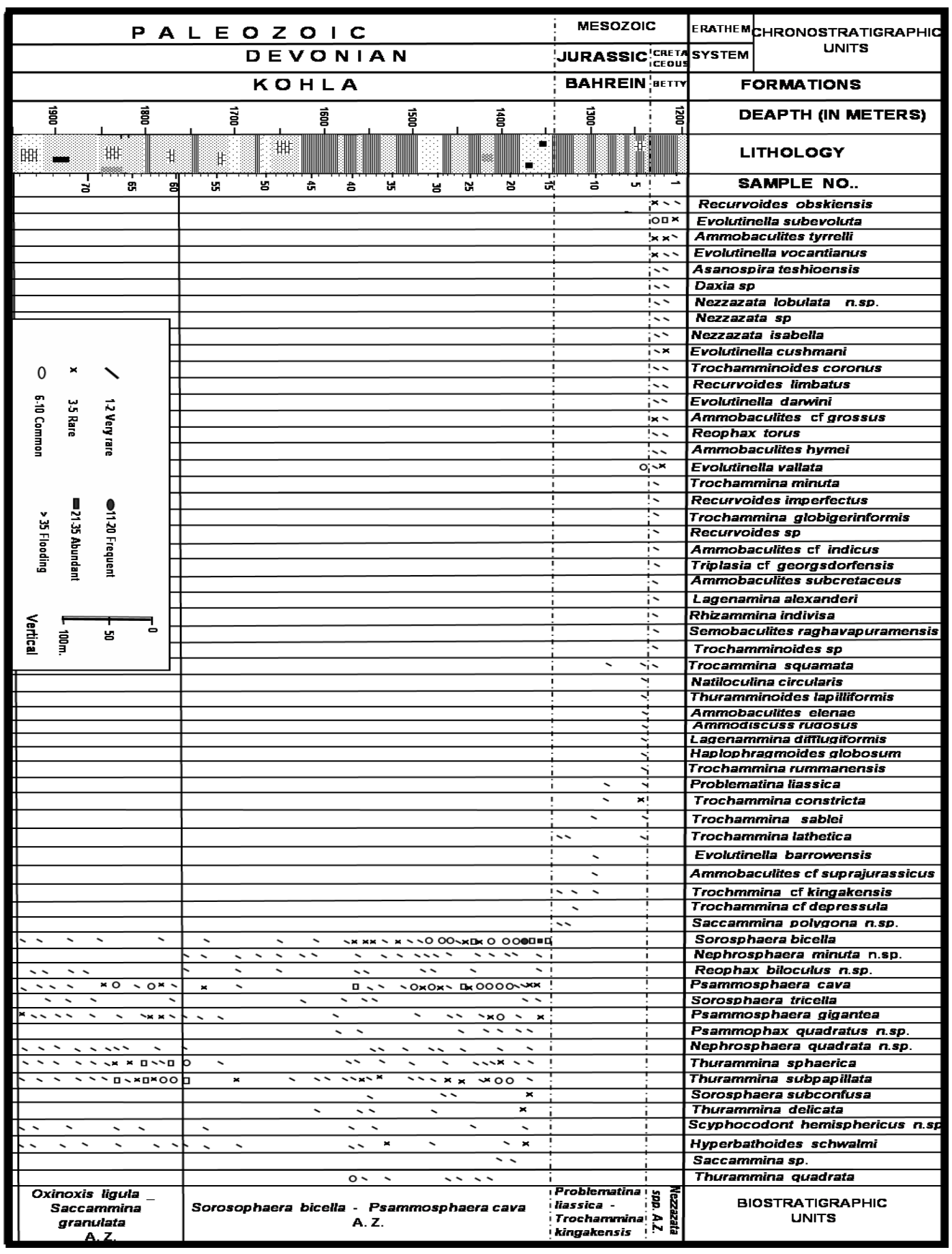


Fig.4 Lithostratigraphic, Biostratigraphic and Echostratigraphic units of the Paleozoic-Mesozoic succession in Bahrei-1 Well

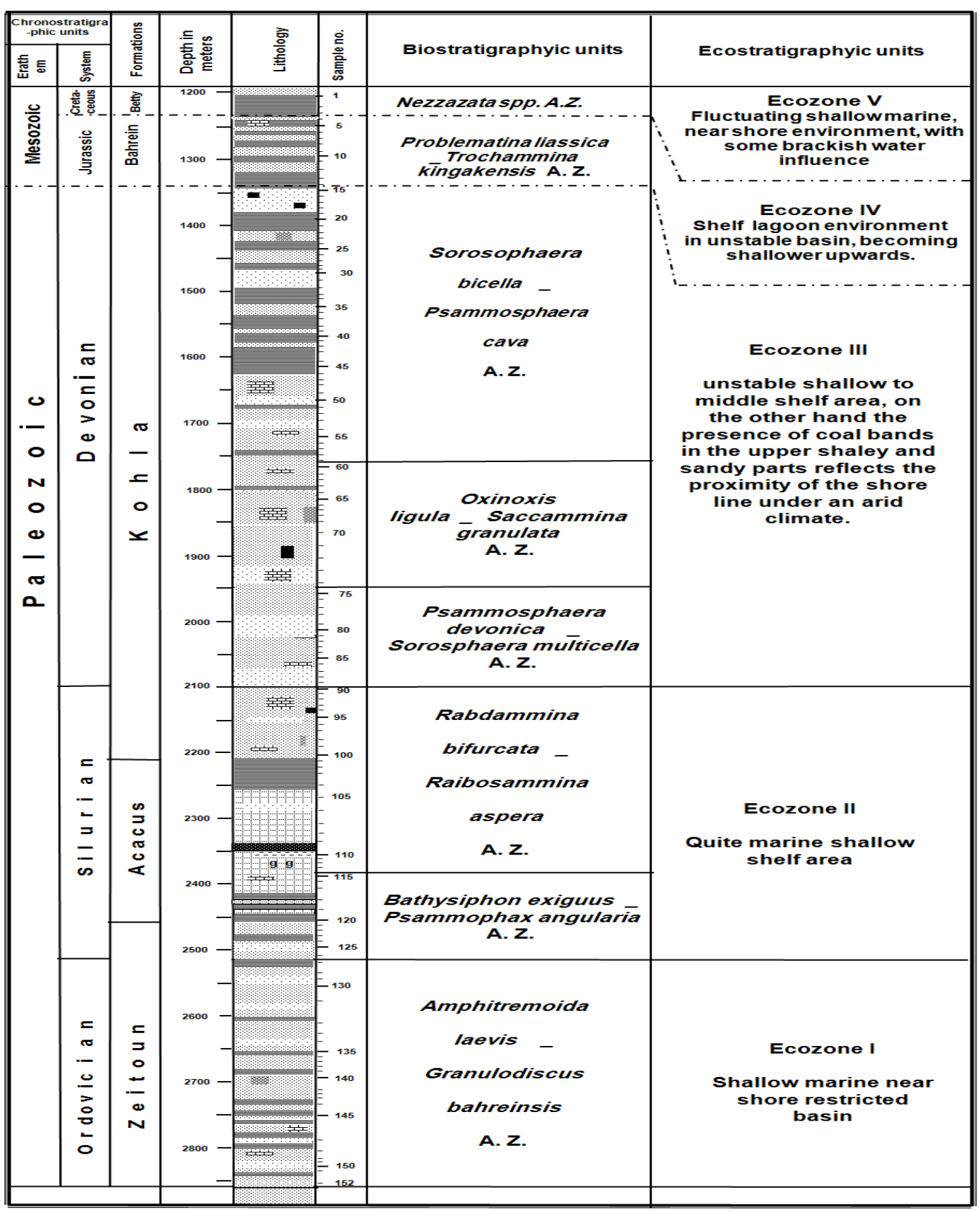


Figure.5 The zonal Paleozoic- Mesozoic Foraminifera of the Bahrein-1 well

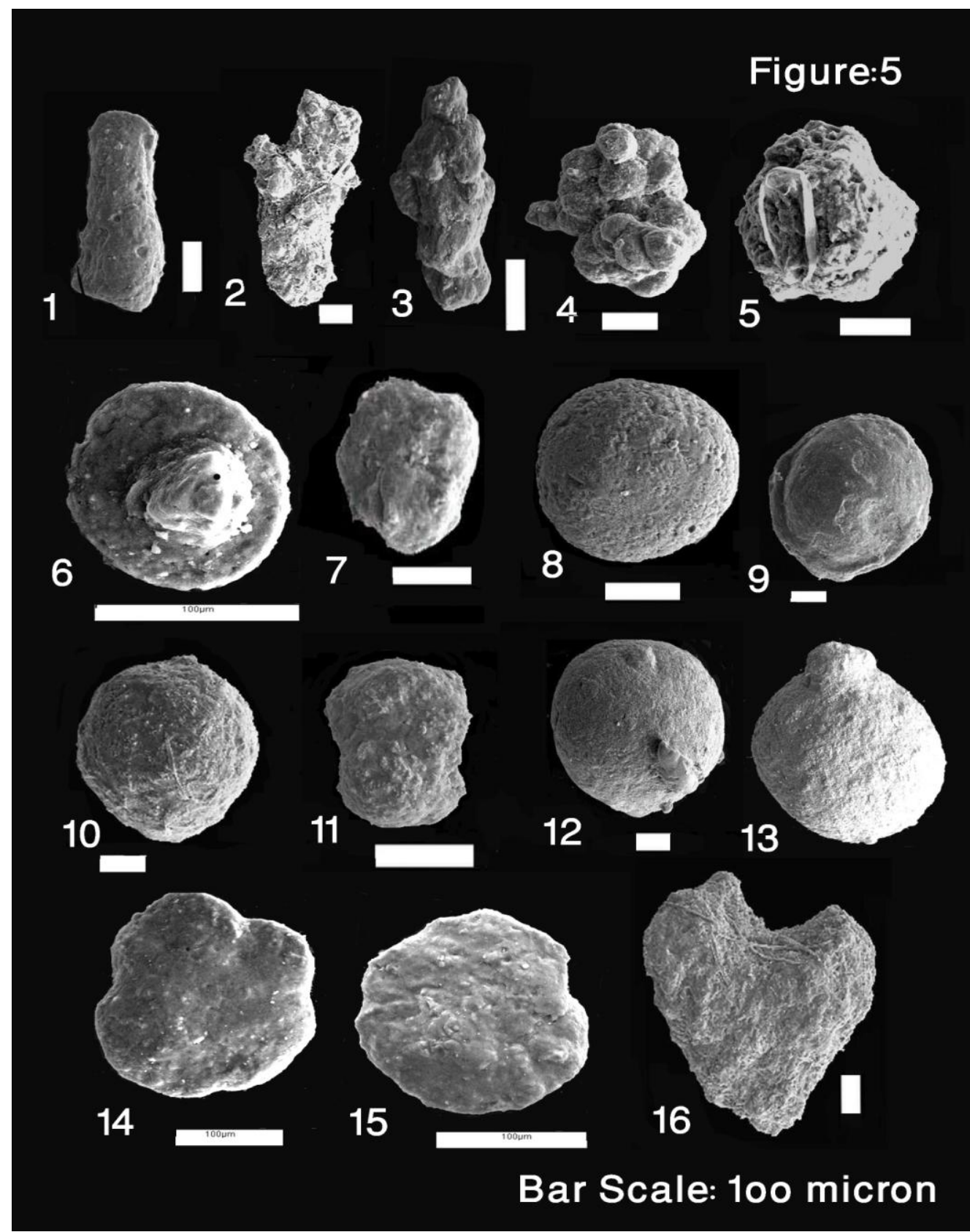

1-Bathysiphon exiguus(Silurian), 2- Raibosammina aspera ( Devonian), 3- Oxinoxis ligula (Devonian),4Sorosphaera multicella (Devonian),5- Psammosphaera angularis(Silurian), 6- Granulodiscus bahreinensis (Ordovician), 7-Trochammina cf Kingakensis (Jurassic) 8- Psammosphaera devonica (Devonian) 9-Proplematina liassica (Jurassic), 10- Psammosphaera cava(Devonian), 11-Sorosphaera bicella (Silurian), 12- Amphitremoida laevis (Ordovician), 13- Saccammina globulata(Devonian), 10- Thurammina subpapillata ( Ireland), 14, 15- Nezzazata lobulata(Lower Cretaceous), 16Rhabdammina bifurcata(Silurian) 
Figure.6 Index Paleozoic- Mesozoic Foraminifera from Bahrein-1well

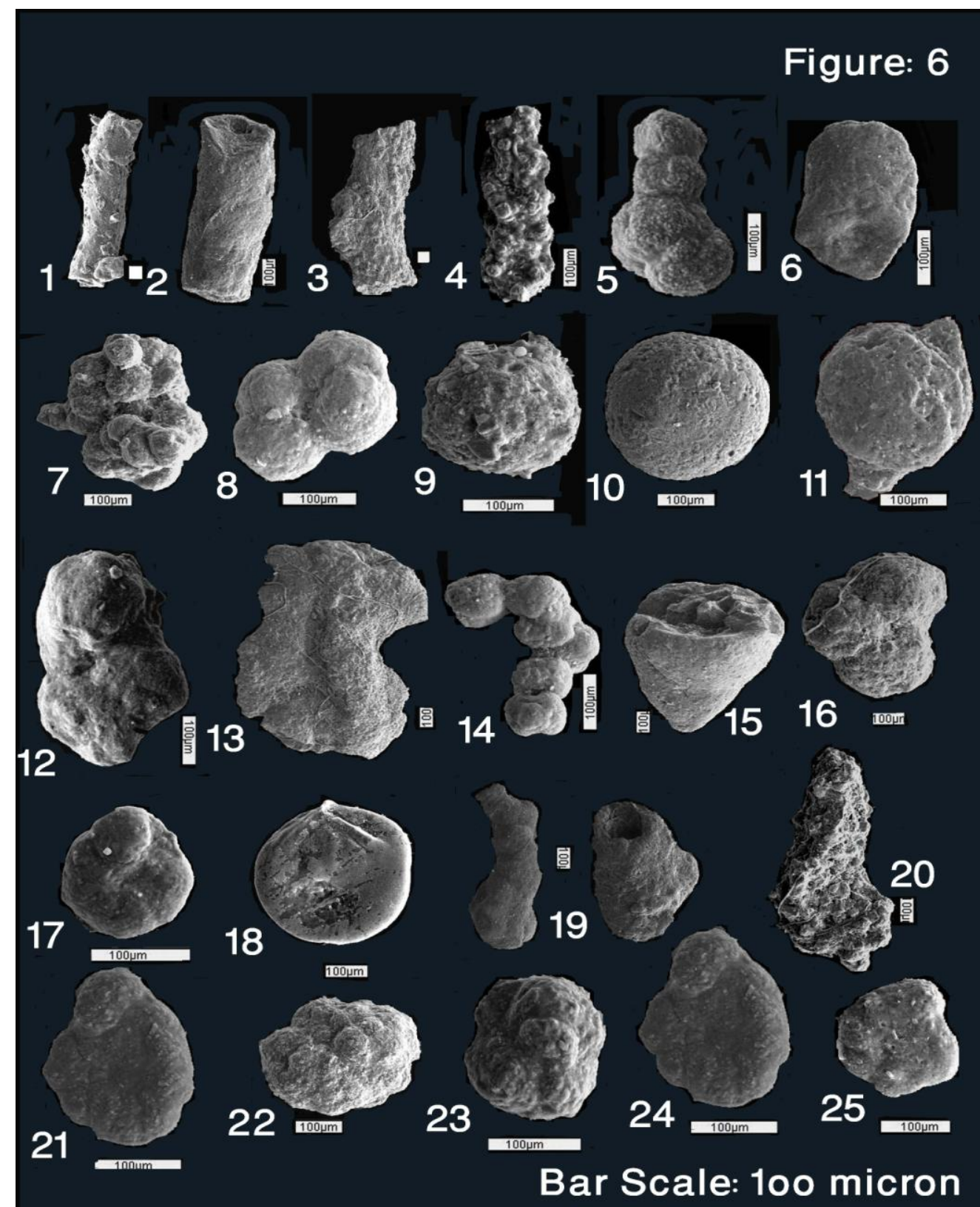

1-Rhaibosammina sp (Silurian), 2-Bathysiphon rugosus (Devonian), 3-Rhabosammina mica (Silurian), 4Ammobaculites cf indicus (Lower Cretaceous), 5-Ammobaculites tyrrelli (Lower Cretaceous), 6Hyperammina harrisi (Silurian), 7- Sorosphaera multicella (Devonian), 8- Sorosphaera osgoodensis(Devonian), 9-Psammosphaera rugosa (Devonian) 10-Psammosphaera pusilla (Devonian), 11-Amphitremoida orbicularis (Ordovician), 12-Ammobaculites suprajurassicus (Jurassic), 8Pseudohyperammina sp.(Devonian), 14- Polycasmmina sp (Silurian), 15- Kechenotiske cf expansus (Devonian), 16- Sorosphaera tricella (Devonian), 17- Recurvoides limbatus (Lower Cretaceous), 18Thuramminoides lapilliformis (Jurassic), 19- Hypramminoides schwalmi (Silurian), 20- Triplasia cf georgsdorfensis (Lower Cretaceous), 21- Evolutinella cushmani (Lower Cretaceous), 22-Thurammina papillata var. monticulifera(Silurian), 23-Trochammina globigeriniformis (Lower Cretaceous) ,25Trochammina rummanensis (Jurassic). 


\section{Foraminiferal Content}

Foraminifera in this interval is common and shows high diversity. There is a common occurrence of Evolutinella, Ammobaculites, Recurvoides, Trochammina, Nezzazata and rare occurrence of Rhizammina, Semibaculites, Trochamminoides, Daxia and Asanospira. The chief controlling factors for high populations of arenaceous species are low calcium carbonate (Walton, 1955) and salinity (Hedberg, 1934; Lowman, 1949; Loeblich and Tappan, 1950; Bandy, 1956; Pokorny, 1963 and others).The predominance of simple and small arenaceous forms, as Ammobaculites, Haplophragmoides etc. Suggests a marshy environment with low and wide fluctuation PH (Bandy, 1960, 1963; Bhalla, 1968, and Abd-Elshafy et al. 2002).

\section{Probable Paleoenvironment}

Fluctuating shallow marine, near shore environment, with some brackish water influence

Regarding to the scope of the study, the studied 152 samples have been collected from the Bahrein -1 Well. The depth of the samples ranges from $2853 \mathrm{~m}$ and depth 1200 $\mathrm{m}$. The main aim is to investigate the foraminiferal assemblages of the PaleozoicMesozoic succession in terms of abundance and diversity, to determine the biostratigraphic and the chronostratigraphic assignments as well as the geographic distributions of the foraminiferal assemblages.

Over and above the formentioned biostratigraphic and chronostratigraphic outcome about the recorded foraminiferal species, there are some additional results can be obtained:

The present Ordovician, Silurian and Devonian foraminiferal biozones are the first established zones in North Africa and may be the surrounding regions as a whole.

The interval of the Lower Jurassic Problematina liassica is a guide and zonal form in the Tethys, Carabathian and North Atlantic (Abd -Elshafy, 1984; Johnson, 1976; Grandstein, 1978; Velic, 2007). The Lower Cretaceous Nezzazata spp .Zone correlates the study area in continuous conjugation with many surrounding regions (Abd-Elshafy and Abu Ellile, 1989; Velac, 2007).

\section{References}

Abdel-Sattar, G. 1979. Biostratigraphy of some subsurface Paleozoic sections in Western Desert, Egypt. M. Sc. Thesis, Faculty of Science, Ain Shams University, Cairo, Egypt.

Abdel-Sattar, G. 1982. Biostratigraphy of Paleozoic rocks north Egypt. Ph. D. Thesis, Faculty of Science, Ain Shams University, Cairo, Egypt.168 $P$.

Abd-Elshafy, E. 1977. Biostratigraphical studies of some Jurassic formations in the Western Desert, Egypt. M.Sc. Thesis, Faculty of Science, Al Azhar University, Cairo, Egypt, 170 p.

Abd-Elshafy, E. 1984. Stratigraphy of the subsurface Jurassic in Qattara Depression and its relation with similar sections in Egypt and in the Tethyan region. African Geol., (J. Kierk and T. Michot, Eds.) Tervuren, 274-259.

Abd-Elshafy, E. 1990. Lithostratigraphy and paleoenvironments of the Qattara Jurassic with some regional aspects on the Egyptian Jurassic. Bull. Faculty of Sci., Zagazig University, Zagazig, Egypt, 12(2): 644-673.

Abd-Elshafy, E., M.M. Abu Ellile. 1989. Stratigraphy and correlation of 
Belayim Cenomanian, Gulf of Suez, Egypt. J. African Earth Sci., 9(1): 77-85, Pergamon press plc.

Abd-Elshafy, E., M.A. Bassiouni and Nagwa Ibrahim. 1998. Stratigraphy of the Jurassic rocks in the Egyptian Western Desert. Geology of the preCretaceous and Development in Egypt, Zagazig, 1: 76 -110.

Andrawis, S.F. 1972. New biostratigraphic contribution for the Upper part of the Paleozoic rocks of Gibb-Afia well no 11, Western Desert, Egypt. 8th Arab Petroleum Conference. Algiers Papers, 76 (B-3), 11P.

Arnaud Vanneau, A. A. and I. P Silva, 1995. Biostratigraphy and systematic description of benthic foraminifers from Middle Cretaceous shallowwater carbonate plat-form sediments at sites 878 and 879 (MIT and Takuyo- Daison Guyots), proceeding of the (ODP), scientific results, Vol. 144.

Barnard, T., 1949. Foraminifera from the Lower Lias of the Dorset Coast. Quarterly J. Geological Society of London, 105 (3): 347-391.

Barthel, K. W. and R. Beottcher, 1978. Abu Ballas Formation (Tithonianl Berriasian; southwestern Desert, Egypt) a significant lithostratigraphic unit of the former "Nubian series". Mitt. Bayer. Staattssamlung Paleontology, Hist. Geol., 18: 153 166.

Browne, R.G. and V.J. Schott, 1963. Arenaceous foraminifera from the Osgood Formation at Osgood, Indiana. Bull. American Paleontol., 46 (209):191-242, Pls. 48-52. .

Conkin, J.E., and B.M. Conkin,. 1970. Middle Devonian arenaceous Foraminifera of central Ohio, Part 1revision of the genus Webbinelloidea Stewart and Lampe, 1947.
Micropaleontol., 16(1): 1-14, Pls. 14.

Dunn, Paul, M., 1942. Silurian Foraminifera of the Mississippian Basin. $J$. Paleontol., 16(3): 317-342, Pls. 4244.

Ebeid, M. Z., 1969. Biostratigraphic study of some Pre-Upper Cretaceous successions in some wells in Western Desert. M.Sc. Thesis, Faculty of Science Ain Shams Univ. Cairo, $132 \mathrm{P}$.

El Hariri, T. Y., 2008. Depositional Environment and Petrophysical Studies on Subsurface Devonian Sediments from Faghur-1x Well at North Western Desert, Egypt J. Appl. Sci. Res., 4(1): 65-75.

Grandstein, M. F., 1978. Jurassic Grand Banks foraminifera. J. foraminiferal Res., 8(2): 97-102.

Hassan, M. W., A.M. Hassanein, and E. Abd-Elshafy, 1978a. New Jurassic foraminiferal fauna from the Western Desert, Egypt. Proceedings of the Egyptian Academy of Science, 31: 9 20.

Hassan, M. Y., A. M. Hassanein, and E. Abdel-Shafy.

$1978 b$

Microbiostratigraphy and timestratigraphy of the subsurface Jurassic formations in Betty area, Western Desert, Egypt. Proceedings of the Egyptian Academy of Science, 31: 22-46.

Hassan, M. W., A. M. Hassanein, and Z. 1. M Sharawy, 1978c. Jurassic stratigraphy of Mamura well, Western Desert, Egypt. Proceedings of the Egyptian Academy of Science, 31: 47 - 57.

Hassanein, A. M. and A. A. Arafa, 1989. Upper Jurassic biostratigraphic zonation of the northern part of the Western Desert, Egypt. Proceedings 
of the Egyptian Academy of Science, 34: $139-143$.

Ibrahim, Nagwa, 1992. Stratigraphy of the Jurassic rocks in the Egyptian Western Desert. Ph. D. Thesis, Faculty of Science, Zagazig University, Egypt, 257 p.

Ireland, H. A., 1956. Upper Pennsylvanian Foraminifera from Kansas. $J$. Paleontology, 30, (4): 831-864, textfigs. 1-7.

Johnson, B., 1976. Ecological ranges selected Toarcian and Demerian (Jurassic) foraminiferal species from Wales. $1^{\text {st }}$ International Symposium on Benthonic foraminifera of continental margins. Part B: Paleoecology and biostratigraphy material sediments, special publication, 1: 545-556.

Klitzsch, E. and A .Lejal-Nicol, 1984. Flora and fauna from strata in southern Sudan (Nubian and surrounding areas). Berliner Geowiss, Abh. (A): 50: 47-80.

Loeblich, A. R. and H. Tappan, 1946. New Washita Foraminifera. J. Paleontol., 20: 238-258, pl. 35-36.

Moreman, W. L., 1930. Arenaceous Foraminifera from Ordovician and Silurian limestone of Oklahoma. $J$. Paleontol., 4 (1): 42-59, Pls. 5-7.

Nagy, J. and V. Basov, 1998. Revised foraminiferal taxa and biostratigraphy of Bathonian to Ryazanian deposits in Spitsbergera. Micropaleontol., 44(3):217-255, text-figures $1-16$, plates $1-8$, tables $1-2$.

Nestell, G. P. and T. Y. Tolmacheva, 2004. Early Ordovician Foraminifera from the lava river section, northwest Russia. Micropaleontol., 50(3): 253280. Text figures 1-5, Pl. 1-11.

Olempska, E., 1983. The Upper Devonian foraminiferas of the Swietokrzyskie
(Holy cross) Mts., Poland. Acta Paleont Plonica, 28(3-4): 393-414, Pls. 13-20.

Olszewska, B. and J. Wieczorek, 2002. Stratigraphic and tectonic position of Cretaceous deposits from podhale basin substratum (polish Carpathians). Geologica Carpathica 53 (CD edition). Polish Geological Institute, Skrzatow, and Krakow.

Osman, A., 1956. The stratigraphy of the Pre - Tertiary subsurface formations of Abu -Roash. Bulletin of the Institute Desert de'Egypt, 37 (3): 217 $-225$.

Romanova, V. I., 1960. In Glazunova, A.E.; Balakhmatova, V.T.; Lipman, R.K.; Romanova, V.I. and Khokhlova, I.A.; Stratigraphy and fuina of the Cretaceous deposits of the west Siberian low land. Leningrad.VSES. Nauchno. LSSLed. Geol. Inst. (VSEGEI) (All-Union Scientific. Research Geological institute), Trudy, 29:1-347, Pls. 1-25.

Said, R. and S. F. Andrawis, 1961. Lower Carboniferous microfossils from the subsurface rocks of the Western Desert of Egypt. Contributions from the Cushman Foundation for Foraminiferal Research, 12(I):22.

Shahin, A., 2000: Contribution to the Bathonian benthic foraminifera and ostracoda and their paleoenvironments in Gabal Al Maghara, northern Sinai, Egypt. Bulletin of the Faculty of Science, Mansura University, 27(2): 1-16.

Souaya, F. J., 1976. Foraminifera of SunGulf-Global Linckens Island Well P46, Arctic Archipelago, Canada. Micropaleontol., 22(3): 249 - 306, 12 Plt.

Stewart, G. A. and L. Lampe, 1947. Foraminifera from the Middle Devonian Bone beds of Ohio. $J$. 
Paleontol., 21(6):529-536, pls. 7879

Sumerson, C. H., 1958. Arenaceous foraminifera from the Middle Devonian Limestone of Ohio. $J$. Paleontol., 32, (3):550.267.

Tappan, H., 1955. Foraminifera from the Arctic slope of Alaska; part II, Jurassic Foraminifera Professional. Paper U.S. Geological Survey, 236 B: 19 - 90.

Velic, I. 2007. Stratigraphy and paleobiogeography of Mesozoic benthic foraminifera of the Karst Dinairdes(S E Europe). Geologica
Croatica, 60(1):1-13, 18 figs., 26pls, Zaghreb.

Weidich, K.F. 1990. Die Kalkalpine Unterkreide und Ihre Foraminiferen fauna. Hablitationsschrift der Fakultat fur Geowissenschaften der L.M.U. Munchen. 522, p. 383.

Yahia, N., 2010. Biostratigraphic calibration and ecostratigraphy of some subsurface Paleozoic - Mesozoic sediments in the north western part of the Egyptian Western Desert. M.Sc. Thesis, Faculty of Science, Zagazig University Zagazig, Egypt, $129 \mathrm{p}$.

\section{How to cite this article:}

Abd El-Azeam S., Nagwa Ibrahim, E. Abd-Elshafy and Yahia Naglaa. 2016. North African Paleozoic- Mesozioic Foraminifera (Biostratigraphy and Echostratigraphy). Int.J.Curr.Microbiol.App.Sci. 5(6): 925-940. doi: http://dx.doi.org/10.20546/ijcmas.2016.506.100 